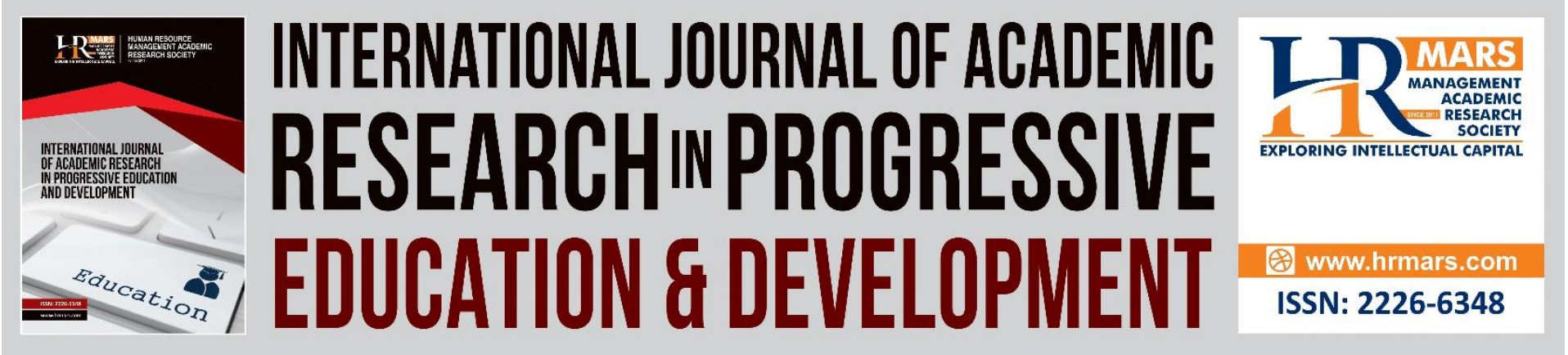

\title{
Awareness and Acceptance toward the Role of Open Education Resources (OER) in Teaching and Learning Aftermath COVID-19 Pandemic: PLS-SEM Approach
}

Siti Sara Ibrahim, Noor Azila Mohd Zaid, Zuliana Zoolkefli, Aini Hayati Musa, Farrah Nadia Baharuddin

To Link this Article: http://dx.doi.org/10.6007/IJARPED/v10-i3/11482

DOI:10.6007/IJARPED/v10-i3/11482

Received: 12 July 2021, Revised: 20 August 2021, Accepted: 12 September 2021

Published Online: 30 September 2021

In-Text Citation: (Ibrahim et al., 2021)

To Cite this Article: Ibrahim, S. S., Zaid, N. A. M., Zoolkefli, Z., Musa, A. H., \& Baharuddin, F. N. (2021). Awareness and Acceptance toward the Role of Open Education Resources (OER) in Teaching and Learning Aftermath COVID-19 Pandemic: PLS-SEM Approach. International Journal of Academic Research in Progressive Education and Development, 10(3), 1095-1106.

Copyright: (c) 2021 The Author(s)

Published by Human Resource Management Academic Research Society (www.hrmars.com)

This article is published under the Creative Commons Attribution (CC BY 4.0) license. Anyone may reproduce, distribute, translate and create derivative works of this article (for both commercial and non-commercial purposes), subject to full attribution to the original publication and authors. The full terms of this license may be seen at: http://creativecommons.org/licences/by/4.0/legalcode

Vol. 10(3) 2021, Pg. 1095 - 1106

http://hrmars.com/index.php/pages/detail/IJARPED

JOURNAL HOMEPAGE

Full Terms \& Conditions of access and use can be found at http://hrmars.com/index.php/pages/detail/publication-ethics 


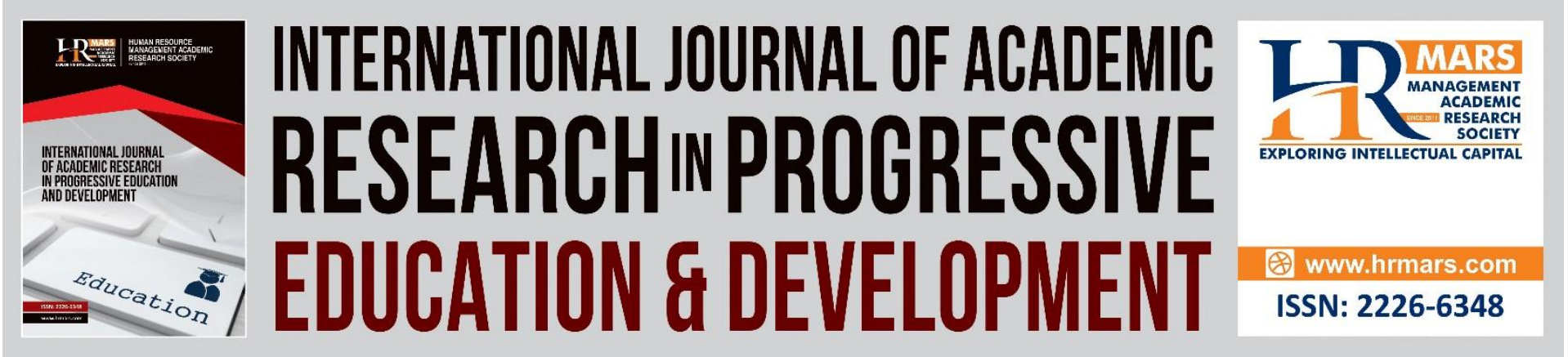

\title{
Awareness and Acceptance toward the Role of Open Education Resources (OER) in Teaching and Learning Aftermath COVID-19 Pandemic: PLS- SEM Approach
}

\author{
Siti Sara Ibrahim, Noor Azila Mohd Zaid, Zuliana Zoolkefli, Aini \\ Hayati Musa, Farrah Nadia Baharuddin \\ Faculty of Business Management, Universiti Teknologi MARA, Cawangan Negeri Sembilan, \\ Kampus Rembau, Malaysia
}

\begin{abstract}
As the COVID-19 pandemic continue worsens, the educational environment is being compelled to shift from traditional classroom or blended teaching modes to online models. The impact of the COVID-19 pandemic on education systems requires further development to ensure the continuity of the teaching and learning process. Open educational resources (OER) are learning materials that are straightforwardly authorized the educators and learners to share and gather related information and permits others to retain, reuse, revise, remix or redistribute (the $5 R s$ ) these materials. Even though OER has numerous advantages, still the awareness and acceptance of this strategy remain low and some also highlighted that all things considered, there are still hurdles to OER implementation in Malaysia. Therefore, this study is aimed to empirically investigate the level of awareness that can influence the acceptance of OER in teaching and learning process. To evaluate the study's hypothesis, PLSSEM 3.0 is used to test the measurement and structural model. A total of 225 respondents is gathers from the students on what is their awareness and acceptance toward the establishment of OER to assist their teaching and learning process especially after the pandemic which has change the traditional method to online based. The finding indicates that awareness is significantly influence the acceptance level toward the establishment of OER with a value of R2 (61.7\%) at more than moderate level that explained the dependent variable. This study is crucial for academics, higher education institutions, and policymakers as a guideline to create proper improvement and enhancement to any problem that arises from the inability and failure of OER.
\end{abstract}

Keywords: Awareness, Acceptance, Open Education Resources (OER), Teaching \& Learning, COVID-19 Pandemic

\section{Introduction}

With the presence of the COVID-19 widespread in Malaysia in 2020, higher education systems around the world were stood up to with creating online courses to complete the semester. 
The COVID-19 widespread has developed rapidly to influence worldwide operations of higher instruction and has called for the require for the arrangement of emergency e-learning and the results for the securitization of higher instruction (Zuhairi et al., 2020; Murphy, 2020). According to Musa et.al (2020), the advancements in learning innovation have challenged the university to change how they plan and provide their programs. By making an environment in which understudies feel comfortable with the thought of technology-based learning, universities can encourage the advancement of a skill set that will empower graduates to proceed to create all through their careers. Hence, effectiveness is the most concern for most of the organization in realizing their objectives and accomplishments. The move to online learning has had a high effect on the way educator approach instructing in a competencyoriented technique because it needs an expound environment where students participate in important learning developments (Zizka \& Probst, 2021; O'Sullivan \& O'Sullivan, 2014).

The impact of the COVID-19 pandemic on education systems requires further development to ensure the continuity of the teaching and learning process. The fast rise in online classrooms amid the COVID-19 widespread has driven the selection of more online resources than ever some time recently (Allen \& Katz, 2020; Schaffhauser, 2020). Regarding to Teng et al (2021), rather than cancelling the educational program, numerous universities energized academicians to offer instructional content and evaluate learning through online distance learning. Currently, e-learning within the higher instruction system is within the preparation of arrangement and advancement. On the other side, it is experienced with expanding demand for services due to COVID-19, expanding competition, advances in technology and the high volume of accessible data. It is essential to adopt suitable arrangements whereas being mindful of the current state of the e-learning system, to improve and upgrade its productivity to reply correctly to the developing request within the nation.

Open educational resources (OER) are learning materials that are straightforwardly authorized, which implies the copyright-holder has distributed the material on the web under a Creative Commons (CC) permit that permits others to retain, reuse, revise, remix or redistribute (the 5Rs) these materials (Allen and Katz, 2020; Wiley and Hilton, 2018). In accordance with Abidin et al (2021), OER consist of full courses, course materials, modules, textbooks, streaming videos, tests, software and tools, materials, or techniques used to sustenance access to information. OER is seen as a good platform to ensure the effectiveness of teaching and learning processes. According to Musa et al (2020), online platforms such as Google Classroom, Google Meet, Facebook Life, Zoom and numerous more are the utmost medium utilized in teaching and learning activity. Subsequently, it makes the feeling of talking to a wall without instant feedback from the student compared to face-to-face atmosphere. OER is perceived to be one of the approaches that can sustenance ODL delivery.

Although OER features a lot of benefits, the awareness and acceptance of this strategy is still low. In accordance with Abidin et. al (2021), all things considered, there are still impediments that are found which might debilitate the adoption of OER in Malaysia. The need for awareness and abilities, the need of intrigued in academic development as well as the need for bolster from the administration level are a few of the obstructions among staff members to create utilize of OER. Consequently, in a way of encouraging better adoption and acceptance of OEL in this country, the institution needs to establish procedures and 
guidelines; thus, it will reassure broader use and reuse of open content. For numerous higher education institutions, the COVID-19 widespread has instructed intense lessons to modernize and move forward indeed quicker to become more innovatively enhanced open and online universities able to reach different bunches of understudies (Zuhairi et al., 2020).

Therefore, this study is aimed to empirically investigate the awareness level that can contribute to the acceptance of OER in teaching and learning. The measurement and structural model are tested in PLS-SEM 3.0 to test the hypothesis of the study. This study is altogether critical to the academicians, higher education institutions and also policymakers as a guideline to create proper improvement and enhancement to any problem emerge from the incapable and unsuccessful of OER.

\section{Literature Review}

\section{Development OF Teaching \& Learning in Malaysia}

The Malaysian Higher Learning Institutions had implemented online learning started in the late 1990s and prosper until the current Vision 2020 that encourages the use of computers and multimedia technology in educational institutions to transforms the education system from memory-based learning into simulative thinking and creativity through access to modern technology (Devan \& Ananda, 2021). In line with the educational developments, The Malaysian education system has evolved by stages which lead to the current Malaysian Education Blueprint (MEB) 2015-2025 (Higher Education) that is shaping to transform the Malaysian Education system by focusing on 11 Shift under the MEB (Zandi et al., 2019).

However, in early 2019, the education system in Malaysia has changed robustly because of the impact of the Covid-19 Pandemic. It has created additional challenges for teaching and learning in Malaysia. All the educational institutions have closed due to the Pandemic. The new approach being implemented is through "Online Learning" and "Blended learning". It has also created new issues in terms of social perspectives (Hizam et al., 2020). Malaysians are facing difficulties financially; many were terminated since March 2020 and are unemployed. The report shows that it impacts the students, whereby they are losing interest in learning (Devan \& Ananda 2021). Both research done by (Hizam et al., 2020) and (Devan \& Ananda, 2021) agreed to continue operating in blended learning or online teaching as a practical approach due to Covid-19.

In the current scenario of Malaysia, the new implementation of online teaching and learning provide advantages for both students and universities (Sevanathan et al., 2020). Students in developed countries such as Korea and Australia opted to have flexible time for learning, which is more convenient for accessing the teaching materials. By implementing this learning method, the universities also gain more cost-effective benefits with a wide audience and no necessities of physical infrastructure (Misko et al., 2004). However, online teaching has a few limitations as the lecturer's faced difficulty in preparing materials for the online method, which is a very time-consuming process. Also, online learning becomes a challenging task in assisting the students in accessing the learning materials as online learning requires less supervision (Sevanathan et al., 2020). 
DEVELOPMENT

Vol. 10, No. 3, 2021, E-ISSN: 2226-6348 @ 2021 HRMARS

\section{Development Of Teaching \& Learning in Malaysia}

In order to mark an important progress and development toward the goal of quality education and access to information, UNESCO's General Conference in November 2019 (UNESCO, 2020a), adopted a recommendation on OER. The recommendation contributes to build open and inclusive knowledge societies that will achieve the objectives of the United Nations Sustainable Development Goals, which focusing on inclusive and equitable quality education and promotes lifelong learning opportunities for all (Ebba et al., 2020).

Due to the current crisis affected by COVID-19 which making massive disruption to education, affecting billion of learners all over the world, UNESCO (2020c) issued a Call to support learning and knowledge sharing through OER worldwide (Ebba et al., 2020). The implementation and paradigm of education systems around the world has totally changed regarding on how learners could access learning. It is resulted the global community comes together now to access to information and knowledge through OER and OEP (Bozkurt, et al., 2020; Huang, et al., 2020).

However, previous study found that OER are a relatively new phenomenon in the Malaysian higher education (HE) sector (Ishan et al., 2013). Several higher education institutions in Malaysia have joined the OER movement, but still, there is not yet widespread understanding about OER and open licences due to the lack of specific guidelines (Commonwealth of Learning, 2017). As reported, In Malaysia, the National eLearning Policy (DePAN 2.0) supported the implementation of OER by focuses on open courseware, and important to develop specific guidelines for the same. Understanding and awareness about OER is gradually growing, especially amongst academics who appreciate the integration of pedagogy and technology.

\section{Awareness on Open Education Resources (OER) in Teaching and Learning}

It clearly shown that OER is one of the new methods of academia in which stimulated innovation in education since year 1999 (Ismail et al., 2019) by sharing learning activities as well as learning resources (Blomgren, 2018). The aims of OER to contribute effective learning experiences as well as to overcome limited printed resources and to fulfil the needs of university students in cramped classes. Thus, OER offers benefits outweigh risks by allows the contents of OER to be adapted, copied, adopted, used as well as re-shares for free as compared to conventional curriculum materials (Ismail et al., 2019).

Moreover, OER grants cost-saving for the university in acquiring free resources for teaching and learning. It also allows instructors to be creative as well as contextual and timely responsive for learning activities (Blomgren, 2018). Due to its importance, creating as well as cultivating awareness on OER requires a crucial understanding to change the perception of teaching and learning via OER (Blomgren, 2018).

The studies on creating awareness on OERs shown that it uses to improve learning environment among students (Shigeta et al., 2017). Its persistence in achieving goals of the sustainable development (DSG) in ensuring equality in education as well as to cultivate lifelong learning for all ages (Ujakpa et al., 2020). As such, it provides free and high quality of educational materials for reuse, revise, redistribution, remix as well as for retain the teaching 
and learning contents (Ujakpa et al., 2020). The previous studies on revealed that students gained high level of awareness on OERs as well as achieved positive perception on OER (Ujakpa et al., 2020) and high level of utilization on different types of OER (Wiche \& Ogunbodede, 2021).

\section{Acceptance on Open Education Resources (OER) in Teaching and Learning}

OER offers benefits outweigh risks by allows the contents of OER to be adapted, copied, adopted, used as well as re-shares for free as compared to conventional curriculum materials (Ismail et al., 2019). OER helps student in learning activities without impact from time, people, space, things as well as matters by getting assistance from the internet. One of the factors that influence acceptance of OER is the convenience of using and implementing OER (Hsiensheng Hsiao et al., 2018). Moreover, factors such as ease to use, OER offers usefulness in teaching and learning activities, students' competencies in using OER as well as facilitating conditions influenced the intention to use OER (Mollel \& Mwantimwa, 2019). The studies were parallel with antecedents of acceptance on OER, namely, open access, easy to use, freedom to reuse, network content, digital as well as community-based approaches (Weller et al., 2018).

The effectiveness of online learning for instance OER can be accomplished if students enjoy the learning activity and familiar with OER (Nisarohmah \& Chodijah, 2021). Previous studies revealed that interface of OER design or OER usability as significant variable for acceptance on online learning (Tao et al., 2019). As such, the evolution of learning by offering OER to massive users without any restrictions on time as well as location limitation, acts as an important supplementary tool for traditional ways of education with the aims to improve quality of education and striving efficiency (Tao et al., 2019). It works to offer alternative in reducing cost of education, the accessibility problem in learning and imbalance distribution of education resources (Tao et al., 2019). Moreover, OER offers under one roof of full courses, modules, streaming videos, course materials, textbooks, software and tools, tests and techniques to use in teaching and learning (Abidin et al., 2021)

\section{Methodology}

The study was employed a quantitative research design using a structured questionnaire and electronically distributed to gain insights on students' awareness and acceptance on the role of OER in teaching and learning. The questionnaire consists of two parts, namely, assessing students' awareness on OER in teaching and learning as well as assessing students' acceptance on OER in teaching and learning. The study involved students from UiTM Negeri Sembilan Kampus Rembau. A total of 225 students from Business and Management were participated in the study. To collect the data, a non-probability sampling, namely, convenience sampling was opted for the study. As such, the sample was considered as representative which enough to make findings on the study to generalize the entire population of UiTM Negeri Sembilan students.

The partial least squares (PLS) method was used to code data and run statistical analysis to gain results to specify the relationship among the factors and to measure underlying of each construct. Moreover, since the sample of the study is relatively small, as such, PLS-SEM 3.0 was found the most appropriate to small sample size. 
The measurement scale used here is adapted and adjusted based on the dimensions of previous research. The awareness is identified and a factor that can influence the acceptance level toward adaptation or implementation of Open Education Resources (OER) in teaching and learning. This made distinctive to guide the higher education sectors to come out with a various platform of OER to assist the development of teaching and learning especially after the pandemic. Besides, the respondents also completed a socio-demographic survey focusing on their gender, courses, and semester in university.

The survey items are measured using the seven-point scale, with responses ranging from "very strongly agree" to "very strongly disagree". The collected data were coded, cleaned, and analysed using the SPSS version 24 software. This study yielded a substantial data set of 225 valid questionnaires for the analysis. Descriptive analysis was used to explore the demographic profile of the sample via the SPSS software. Meanwhile, the SmartPLS 3.11 software assesses both the measurement and structural model analysis.

\section{Analysis \& Findings}

Measurement Model

For the measurement model, the loadings, average variance extracted (AVE), and the composite reliability (CR) were assessed. The values of loadings should be $\geq 0.5$, the AVE should be $\geq 0.5$, and the CR should be $\geq 0.7$ (Hair et al., 2017). Table 1 indicates that the measurement model has satisfactory discriminant validity.

Table 1. Inner path model coefficients and their significance

\begin{tabular}{|c|c|c|c|c|c|}
\hline Code & Items & Loading & CA & CR & AVE \\
\hline \multicolumn{2}{|c|}{ Acceptance } & & $\begin{array}{l}0.96 \\
2\end{array}$ & $\begin{array}{l}0.97 \\
1\end{array}$ & $\begin{array}{l}0.86 \\
9\end{array}$ \\
\hline A1 & $\begin{array}{l}\text { I have heard OER is digitized materials offered } \\
\text { freely and openly for educators, students, and } \\
\text { self-learners to use and reuse for teaching, } \\
\text { learning, and research. }\end{array}$ & 0.899 & & & \\
\hline A2 & $\begin{array}{l}\text { I understand that OER is a platform which makes } \\
\text { the study easier. }\end{array}$ & 0.913 & & & \\
\hline A3 & $\begin{array}{l}\text { I understand that OER is attractive platform that } \\
\text { provide students with materials for teaching } \\
\text { and learning }\end{array}$ & 0.951 & & & \\
\hline A4 & $\begin{array}{l}\text { I understand that OER is an effective teaching } \\
\text { platform for student. }\end{array}$ & 0.933 & & & \\
\hline A5 & $\begin{array}{l}\text { I understand that OER is a complete one stop } \\
\text { centre which provides the materials for } \\
\text { teaching and learning, for example notes, } \\
\text { power point slides, guidelines, and samples of } \\
\text { assignments. }\end{array}$ & 0.943 & & & \\
\hline \multicolumn{2}{|c|}{ Awareness } & & 0.96 & $\begin{array}{l}0.96 \\
9\end{array}$ & $\begin{array}{l}0.86 \\
1 \\
\end{array}$ \\
\hline
\end{tabular}




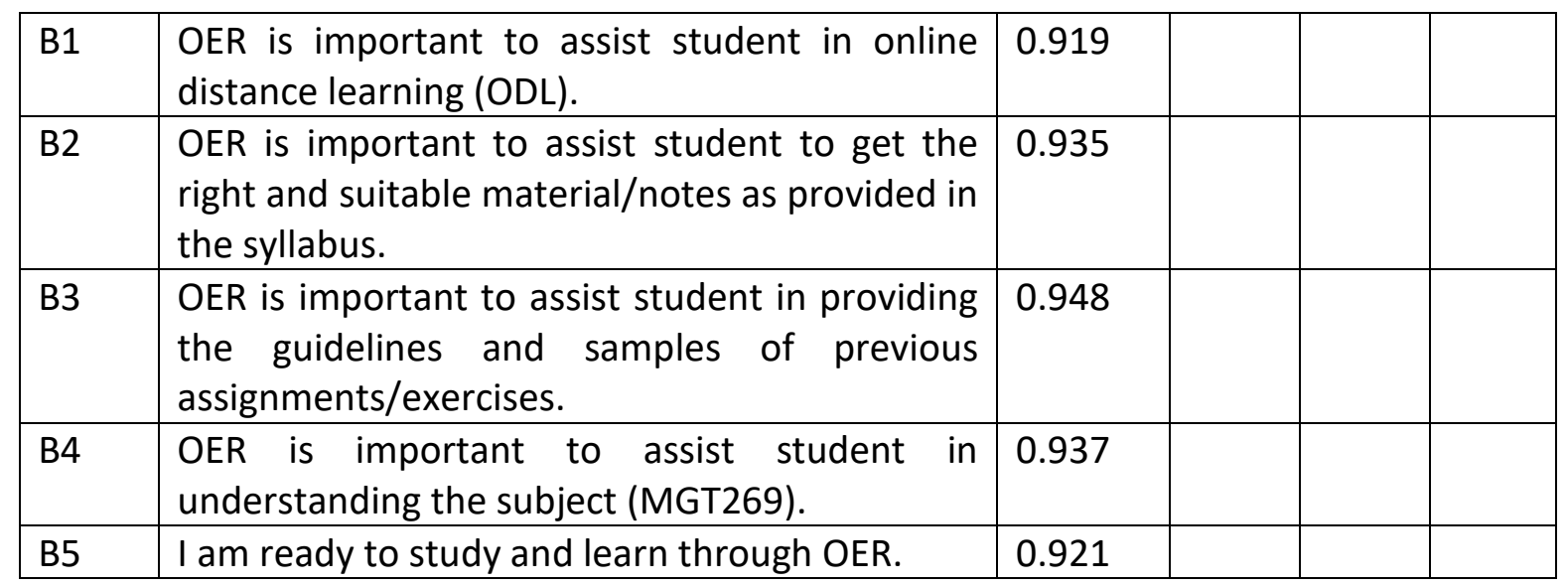

Table 2. HTMT assessment

\begin{tabular}{|l|l|l|}
\hline & Acceptance & Awareness \\
\hline Acceptance & & \\
\hline Awareness & 0.815 & \\
\hline
\end{tabular}

The Heterotrait-Monotrait (HTMT) ratio was opted against the traditional and commonly used Fornell-Larcker's criterion to test the model's discriminant validity (Henseler et al., 2009). The conservative HTMT recommended value should be lower than the 0.85 ratios. Thus, the HTMT value was below the recommended value $(<0.90)$, as reported in Table 2 . Then, Figure 1 below illustrate the relationship between construct of the study.

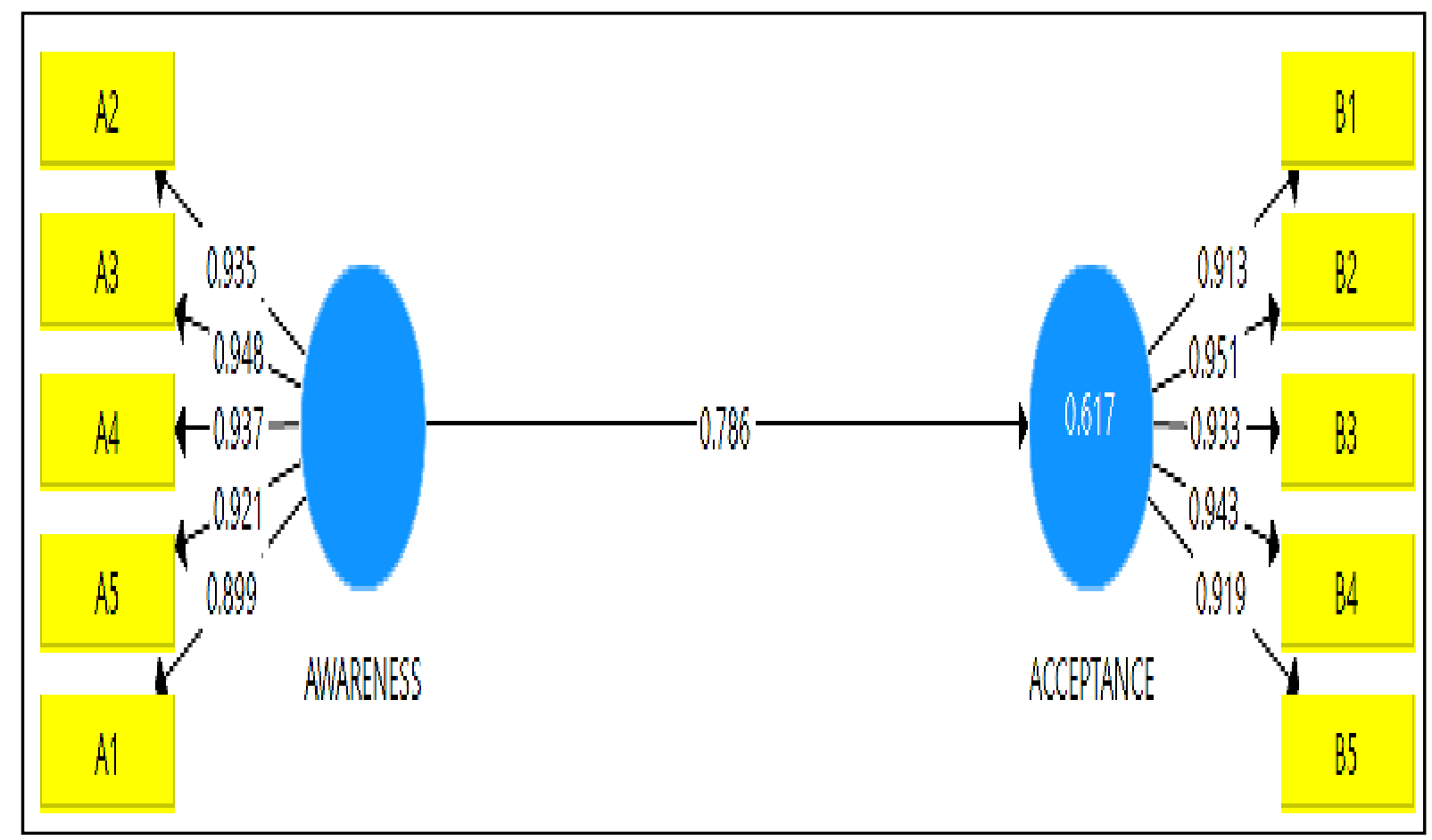

Figure 1. Measurement model 
DEVELOPMENT

Vol. 10, No. 3, 2021, E-ISSN: 2226-6348 @ 2021 HRMARS

\section{Structural Model}

The study hypotheses claimed a significant relationship between cosntructs as below that required to be tested through a structural model of analysis in Partial least squares (PLS) modelling.

H1: There is significant relationship between awareness and acceptance level toward the establishment of OER in teaching and learning

Therefore, Table 3 presents the path coefficient based on the structural model assessment. Following to Hair et al. (2019) the path coefficients, the standard errors, $t$-values and $p$-values for the structural model using a 5,000- sample re-sample bootstrapping procedure were reported (Ramayah et al., 2018). This study confirms that awareness $\left(\beta=0.786^{* * *} ; p<0.01\right.$ ) significantly influence the acceptance level construct. The result proved a positive direct relationship between awareness on the importance of OER toward its acceptance level of the establishment of this platform to assist the teaching and learning process as illustrated Table 3 below.

Table 3. Path analysis

\begin{tabular}{|l|l|l|l|l|l|}
\hline Path & Beta value & Std error & t-values & $p$-values & F-square \\
\hline AWARENESS -> ACCEPTANCE & 0.786 & 0.045 & 17.597 & $0.000 * * *$ & 1.612 \\
\hline
\end{tabular}

Notes: R2=0.617; Q2=0.531; $\mathrm{p}$-value $<0.001 * * *$

The R2 for this study was higher than 0.50 , which is considered moderate accordingly to the rule of thumb of behavioural research in the field of marketing (Hair et al., 2017). The R2 for this study was 0.617 , which is considered moderate accordingly to the rule of thumb of behavioural research in the field of marketing (Hair et al., 2017). The predictive sample reuse technique (Q2) was also used to evaluate the predictive relevance of the structural model (Chin, 1998). The findings support the prediction accuracy of both study models.

\section{Conclusion \& Recommendations}

Covid-19 Pandemic has impacted changes in teaching and learning from traditional method of face-to-face to online or blended learning. Thus, current education systems require further development to ensure the continuity of the teaching and learning process. However, online teaching has some limitations because lecturers had difficulty preparing materials for the online method, which is a time-consuming process. Furthermore, because online learning requires less supervision, it becomes a difficult task to assist students in accessing learning materials. Therefore, student awareness and skills in using this online platform is crucial to ensure they can have access to any open resource platform to gather information for the subjects. The finding illustrated from the study has significantly shown that awareness play an important role for the learners to accept all this changes and use the platform established in an open heart because this requires their patient and interest to use the open resources platform. Indeed, these open resources platform should benefit the learners and educator to assist their teaching and learning as well as assignment and assessment in future.

However, of course the study will have some space for improvement due to its limitation. Thus, it is suggested for a future study to take into consideration on the other factors as the 
findings on R2 in the study as well shown that only $61.7 \%$ of awareness as a construct represent the factors to influence the acceptance level toward the establishment of Open Education Resources (OER) platform to assist in teaching and learning process especially during and after the pandemic that require online method of teaching \& learning. Then, the study as well can be extending to the other private university as the current study only represent the respondent from public university.

\section{Corresponding Author}

Siti Sara Ibrahim. Faculty of Business Management, Universiti Teknologi MARA, Cawangan Negeri Sembilan, Kampus Rembau, Malaysia.

Email: saraibrahim@uitm.edu.my

\section{References}

\section{Journal article}

Abidin, N. F. Z., Kamarulzaman, M. H. K., Idris, A. R., Noh, S. N. S., Musa, A. H., Baharuddin, F. N., Rosle, A. N., \& Ibrahim, S. S. (2021). Open Educational Resources to Support Effective ODL Delivery: A Conceptual Review. International Invention, Innovative \& Creative (InIIC) Conference, 78-82.

Blomgren, C. (2018). OER awareness and use: The affinity between higher education and K12. International Review of Research in Open and Distance Learning, 19(2), 55-70. https://doi.org/10.19173/irrodl.v19i2.3431

Devan, A. (2021). History of Malaysian Education System: Year 1824 to 2025. 10.2139/ssrn.373572. SSRN Electronic Journal (4).

https://www.researchgate.net/publication/348415940_History_of_Malaysian_Educati on_System_Year_1824_to_2025

Ebba, O., Xiangyang Z., Jennryn W., Cristine G., Cengiz H. A., Rajiv J., James G., Mpine, M., Dhaneswar, H. (2020). From Open Educational Resources to Open Educational Practices. https://doi.org/10.4000/dms.5393

Hair, J. F., Hult, G. T. M., Ringle, C. M., Sarstedt, M., \& Thiele, K. O. (2017). Mirror, mirror on the wall: a comparative evaluation of composite-based structural equation modeling methods. Journal of the academy of marketing science, 45(5), 616-632.

Hair, J. F., Risher, J. J., Sarstedt, M., \& Ringle, C. M. (2019). When to use and how to report the results of PLS-SEM. European business review.

Hizam, S. M., Sivalingam, A. D., \& Zandi, G. (2020). A Research Study by Delphi Technique in School Counseling. Test Engineering \& Management, 82(January), 0193-4120. Test Engineering and Management 82(1):5607-5615

Mollel, M. M., \& Mwantimwa, K. (2019). Users' acceptance of e-resources usage at the Institute of Finance Management, Tanzania. International Journal of Education and Development Using Information and Communication Technology, 15(4), 5-21.

Murphy, M. P. A. (2020), "COVID-19 and emergency elearning: consequences of the securitization of higher education for post-pandemic pedagogy", Contemporary Security Policy, Vol. 41 No. 3, pp. 492-505. doi: 10.1080/13523260.2020.1761749.

Musa, A. H., Rosle, A. N., Baharuddin, F. N., \& Ibrahim, S. S. (2020). Challenges in Online Distance Learning (ODL) Delivery during Covid-19 Pandemic Cricis. The Interdisciplinary of Management, Economic and Social Research. 6-11. 
Musa, A. H., Rosle, A. N., Baharuddin, F. N., \& Ibrahim, S. S. (2020). The Effectiveness of Online Distance Learning (ODL) Approach in University: A Respond of Covid-19 Pandemic Crisis. International Journal of Academic Research in Business and Social Sciences. 10(9), 10691076.

Nisarohmah, L., \& Chodijah, M. (2021). The Effectiveness of Online Learning in Increasing Student Productivity. Gunung Djati Conference ..., 4, 762-769. https://conferences.uinsgd.ac.id/index.php/gdcs/article/view/405

O'Sullivan, N., \& O'Sullivan, B. A. (2014), "Teaching and learning in competency-based education", Retrieved 20 January 2021, available at: ww.researchgate.net/publication/269810124_Teaching_and_Learning_in_Competenc Y_Based_Education.

Schaffhauser, D. (2020), "Updated: Free resources for schools during COVID-19 outbreak", THE Journal, 13 April, available at: https://thejournal.com/articles/2020/03/13/freeresources-ed-tech-companies-step-up-during-coronavirus-outbreak.aspx (accessed 16 August 2021).

Selvanathan, M., Hussin, N. A. M., \& Azazi, N. A. N. (2020). Students learning experiences during COVID-19: Work from home period in Malaysian Higher Learning Institutions. Teaching Public Administration. https://doi.org/10.1177/0144739420977900

Shigeta, K., Koizumi, M., Sakai, H., Tsuji, Y., Inaba, R., \& Hiraoka, N. (2017). A survey of the awareness, offering, and adoption of OERs and MOOCs in Japan. Open Praxis, 9(2), 195. https://doi.org/10.5944/openpraxis.9.2.568

Tao, D., Fu, P., Wang, Y., Zhang, T., \& Qu, X. (2019). Key characteristics in designing massive open online courses (MOOCs) for user acceptance: an application of the extended technology acceptance model. Interactive Learning Environments, 0(0), 1-14. https://doi.org/10.1080/10494820.2019.1695214

Teng, L., Tan, Q. \& Ehsani, A. (2021), "Assessing the impact of cultural characteristics, economic situations, skills and knowledge on the development and success of cloudbased e-learning systems in the COVID-19 era", Kybernetes, Vol. ahead-of-print No. ahead-of-print. https://doi-org.ezaccess.library.uitm.edu.my/10.1108/K-12-2020-0838

Ujakpa, M. M., Kiana, L., Iyawa, G. E., Osakwe, J. O., \& Mchombu, K. (2020). Students Awareness and Perception of Open Educational Resources: A case study of the International University of Management, Namibia. International Conefrence on Teaching, Assessment and Learning in the Digital Age, January, 290-299. https://doi.org/10.13140/RG.2.2.26238.00320/1

UNESCO. (2019). Futures of Education https://en.unesco.org/news/new-unescorecommendation-will-promote-access-educational-resources-all

UNESCO. (2020a). Recommendation on Open Educational Resources (OER).Ref: CL/4319. Retrieved:

http://portal.unesco.org/en/ev.phpURL_ID=49556\&URL_DO=DO_TOPIC\&URL_SECTIO $\mathrm{N}=201 . \mathrm{html}$

Van Allen, J., \& Katz, S. (2020), "Teaching with OER during pandemics and beyond", Journal for Multicultural Education, Vol. 14 No. 3/4, pp. 209-218. https://doiorg.ezaccess.library.uitm.edu.my/10.1108/JME-04-2020-0027

Weller, M., Jordan, K., DeVries, I., \& Rolfe, V. (2018). Mapping the open education landscape: citation network analysis of historical open and distance education research. Open Praxis, 10(2), 109. https://doi.org/10.5944/openpraxis.10.2.822 
Wiche, H. I., \& Ogunbodede, K. F. (2021). Awareness and Use of Open Educational Resources By Library And Information Science Students Of Ignatius Ajuru University Of Education, Rivers State, Nigeria. Library Philosophy and Practice, 2021, 1-17.

Wiley, D., \& Hilton, J. (2018), "Defining OER-enabled pedagogy", The International Review of Research in Open and Distributed Learning, Vol. 19 No. 4, doi: 10.19173/irrodl. v19i4.3601.

Zandi, G., Sivalingam, A. D., \& Mansori, S. (2019). An Empirical Study in Human Resource Management to Optimize Malaysian School Counselling Department. International Journal of Financial Research, 10(5), 32. https://doi.org/10.5430/ijfr.v10n5p32

Zizka, L., \& Probst, G. (2021), "Teaching during COVID-19: faculty members' perceptions during and after an "exceptional" semester", Journal of International Education in Business, Vol. ahead-of-print No. ahead-of-print. https://doiorg.ezaccess.library.uitm.edu.my/10.1108/JIEB-12-2020-0099

Zuhairi, A., Raymundo, M. R. D. R., \& Mir, K. (2020), "Implementing quality assurance system for open and distance learning in three Asian open universities: Philippines, Indonesia and Pakistan", Asian Association of Open Universities Journal, Vol. 15 No. 3, pp. 297320. https://doi-org.ezaccess.library.uitm.edu.my/10.1108/AAOUJ-05-2020-0034

\section{Book}

Chin, W. W. (1998). The partial least squares approach to structural equation modeling. Modern methods for business research, 295(2), 295-336.

Commonwealth of Learning. (2017). Towards national policy guidelines on open educational resources in Malaysia. (Page 1-56)

Ismail, M. J., Mgeni, M. S., Yunus, S. A. S., Abdulla, A. A., \& Ahmada, R. I. (2019). Awareness of Open Education Resources (OER) in Higher Learning Institutions. Perspectives from Undergraduate Students from the State University of Zanzibar (SUZA) Maryam. IFIP Advances in Information and Communication Technology, 564, 225-234. https://doi.org/10.1007/978-3-030-28764-1_25

Huang, R., Liu, D., Tlili, A., Knyazeva, S., Chang, T. W., Zhang, X., Burgos, D., Jemni, M., Zhang, M., Zhuang, R., \& Holotescu, C. (2020). Guidance on Open Educational Practices during School Closures: Utilizing OER under COVID-19 Pandemic in line with UNESCO OER Recommendation. Beijing: Smart Learning Institute of Beijing Normal University.

Ishan, S. A., Gajaraj, D., \& Lim, C-K. (2013). In book: Open Educational Resources: An Asian Perspective (pp.119-132). Chapter: 7. Publisher: Commonwealth of Learning and OER Asia 